\title{
Do We Need Three Players in COPD Treatment?
}

\author{
P. Maestrelli ${ }^{a}$ P. Mason ${ }^{\text {a }} \quad$ F. Costa ${ }^{\text {b }}$ P. Paggiaro ${ }^{\text {b }}$ \\ a Department of Cardiologic, Thoracic and Vascular Sciences, University of Padua, Padua, and \\ ${ }^{b}$ Department of Surgery, Medicine, Molecular Biology and Critical Care, University of Pisa, Pisa, Italy
}

Chronic obstructive pulmonary disease (COPD) is a common respiratory disease that represents the third leading cause of death and disease burden worldwide. By definition, it is treatable, but the effectiveness of the current treatment is unsatisfactory since it results in little changes in the natural history of the disease [1]. Drugs for stable COPD reduce the symptoms, frequency, and severity of exacerbations and improve the quality of life and exercise tolerance, but none of them consistently attenuate the progressive decline in $\mathrm{FEV}_{1}$. The positive effects on $\mathrm{FEV}_{1}$ decline obtained with an inhaled corticosteroid/ long-acting $\beta_{2}$-agonist (ICS/LABA) combination or tiotropium (Tio) have been demonstrated only in post hoc analysis or subanalysis of the TORCH and UPLIFT studies $[2,3]$. Furthermore, few data have been reported on the ability of the current drugs to modify biomarkers of remodeling in COPD patients $[4,5]$. Triple combination therapy with anticholinergics, ICS, and LABA improved pulmonary function and symptoms in COPD patients [6], but the mechanism behind the increased efficacy has not been studied.

In the current issue of Respiration, Hoshino and Ohtawa [7] report the effects of Tio plus salmeterol and fluticasone propionate (SFC) on airway dimensions as assessed by chest tomography (CT) scan in COPD patients. A total of 60 COPD patients were treated for 16 weeks with Tio $18 \mu \mathrm{g}$ once daily, salmeterol (SM) $50 \mu \mathrm{g}$ twice daily, SFC 50/250 $\mu$ g twice daily, or Tio $18 \mu$ g once daily plus SFC 50/250 $\mu \mathrm{g}$ twice daily. Pulmonary function, CT, and assessment of health-related quality of life were carried out at screening and at the end of treatment. The right upper lobe apical segmental bronchus (RB1) was chosen for the analysis. The luminal area (Ai), total area of the airway $(\mathrm{Ao})$, wall area $(\mathrm{WA}=\mathrm{Ao}-\mathrm{Ai})$, percentage wall area $(\mathrm{WA} \%=\mathrm{WA} / \mathrm{Ao} \times 100)$, and absolute wall thickness were automatically computed. The addition of Tio to SFC significantly increased the Ai and decreased the airway wall thickness. Furthermore, $\mathrm{FEV}_{1}$ significantly increased in the Tio-plus-SFC group compared with the other groups and this effect was correlated with the changes in Ai and WA. Anatomical and functional changes were associated with greater improvements in SGRQ subscores of symptoms and activity in the Tioplus-SFC group compared with the Tio, SM, and SFC groups.

To our knowledge, this is the first study relating triple therapy with the combination of two bronchodilators and an ICS to CT scan measures of airways wall structural changes. Despite the limited number of patients studied, the authors were careful in controlling for confounders; measurements were standardized for body surface area, and lung volume and total airway dimensions were assessed and were not modified by treatment. Therefore, the changes were due to a redistribution of $\mathrm{Ai}$ and WA.

\section{KARGER}

E-Mail karger@karger.com

www.karger.com/res
(C) 2013 S. Karger AG, Basel

0025-7931/13/0864-0275\$38.00/0
Prof. Piero Maestrelli

Dipartimento di Scienze Cardiologiche, Toraciche e Vascolari

Università degli Studi di Padova

Via Giustiniani 2, IT-35128 Padua (Italy)

E-Mail piero.maestrelli@ unipd.it 
The explanation for the findings remains undetermined. One possibility is geometrical in nature due to more bronchodilation under triple treatment, since the second CT was performed while the subjects were under the effect of bronchodilators. This explanation is in line with the correlation between airway structural changes and $\mathrm{FEV}_{1}$. Since the total airway area did not change, reduced folding of the mucosa during bronchodilation might be admitted for increased luminal area and decreased thickness.

A second more interesting hypothesis is an effect on airway remodeling. Despite several studies showing an improvement in markers of airway inflammation in COPD patients treated with ICS or ICS/LABA combinations $[4,5,8]$, limited observations have been reported on the effects on airway remodeling $[9,10]$. The hypothesis that triple therapy may modify airway remodeling in COPD is particularly interesting and requires confirmation in a large long-term clinical trial. If a reduction in the remodeling process is obtainable with triple therapy, this might change the current recommendations of treating patients with increasing levels of pharmacologic therapy only in relation to the severity of symptoms and airway limitation [1]. If triple therapy has the possibility to modify $\mathrm{FEV}_{1}$ decline, which is greater in mild-moderate than in severe COPD patients, then it should be initiated from the beginning of the disease and not at the end stage of COPD. Obviously, this should be balanced by the higher risk of long-term side effects and the higher cost of the treatment.

The paper from Hoshino and Ohtawa [7] has, however, some limits. Firstly, a treatment arm with Tio and SM association without ICS was not considered, leaving open the question of whether ICS are needed to see such changes. Secondly, the study has a low number of patients in each arm and did not include a placebo one. Thirdly, the bronchodilating effect of treatment is a confounder in the interpretation of the results. If changes in airway wall thickness had been detected after triple treatment in CT scans performed after withdrawal of bronchodilators for an appropriate interval, the hypothesis of an airway remodeling would be stronger. Finally, only one segmental bronchus (RB1) was assessed and, even though Aysola et al. [11] suggested that airway measurements of RB1 correlated with other proximal airways, this method does not provide information on the peripheral lung where relevant pathologic processes take place [12].

In summary, the study gives some support to the potential usefulness of triple combination therapy in the management of COPD. However, the relationship between clinical, physiological, and inflammatory features of COPD and remodeling is still poorly understood.

\section{References}

1 Global Initiative for Chronic Obstructive Lung Disease: Global strategy for diagnosis, management and prevention of chronic obstructive pulmonary disease. 2012. http:// www.goldcopd.org.

-2 Celli BR, Thomas NE, Anderson JA, Ferguson GT, Jenkins CR, Jones PW, Vestbo J, Knobil K, Yates JC, Calverley PM: Effect of pharmacotherapy on rate of decline of lung function in chronic obstructive pulmonary disease: results from the TORCH study. Am J Respir Crit Care Med 2008;178:332-338.

$>3$ Decramer M, Celli B, Kesten S, Lystig T, Mehra S, Tashkin DP: UPLIFT investigators: Effect of tiotropium on outcomes in patients with moderate chronic obstructive pulmonary disease (UPLIFT): a prespecified subgroup analysis of a randomised controlled trial. Lancet 2009;374:1171-1178.

4 Roth M, Johnson PR, Rüdiger JJ, King GG, Ge Q, Burgess JK, Anderson G, Tamm M, Black JL: Interaction between glucocorticoids and beta2 agonists on bronchial airway smooth muscle cells through synchronized cellular signalling. Lancet 2002;360:1293-1299.

$\checkmark 5$ Barnes NC, Qiu YS, Pavord ID, Parker D, Davis PA, Zhu J, Johnson M, Thomson NC, Jef- fery PK: SCO30005 Study Group: Antiinflammatory effects of salmeterol/fluticasone propionate in chronic obstructive lung disease. Am J Respir Crit Care Med 2006;173:736743.

6 Aaron SD, Vandemheen KL, Fergusson D, Maltais F, Bourbeau J, Goldstein R, Balter M, O’Donnell D, McIvor A, Sharma S, Bishop G, Anthony J, Cowie R, Field S, Hirsch A, Hernandez P, Rivington R, Road J, Hoffstein V, Hodder R, Marciniuk D, McCormack D, Fox G, Cox G, Prins HB, Ford G, Bleskie D, Doucette S, Mayers I, Chapman K, Zamel N, Fitzgerald M: Canadian Thoracic Society/Canadian Respiratory Clinical Research Consortium: Tiotropium in combination with placebo, salmeterol, or fluticasone-salmeterol for treatment of chronic obstructive pulmonary disease: a randomized trial. Ann Intern Med 2007;146:545-555.

7 Hoshino M, Ohtawa J: Effects of tiotropium and salmeterol/fluticasone propionate on airway wall thickness in COPD. Respiration 2013;86:280-287.

8 Bourbeau J, Christodoulopoulos P, Maltais F, Yamauchi Y, Olivenstein R, Hamid Q: Effect of salmeterol/fluticasone propionate on air- way inflammation in COPD: a randomised controlled trial. Thorax 2007;62:938-943.

-9 Pera T, Zuidhof A, Valadas J, Smit M, Schoemaker RG, Gosens R, Maarsingh H, Zaagsma J, Meurs H: Tiotropium inhibits pulmonary inflammation and remodelling in a guinea pig model of COPD. Eur Respir J 2011;38:789796.

10 Holownia A, Mroz RM, Skopinski T, Kolodziejczyk A, Chyczewska E, Braszko JJ: Tiotropium increases PPAR $\gamma$ and decreases CREB in cells isolated from induced sputum of COPD patients. Adv Exp Med Biol 2013; 756:9-14

11 Aysola RS, Hoffman EA, Gierada D, Wenzel S, Cook-Granroth J, Tarsi J, Zheng J, Schechtman KB, Ramkumar TP, Cochran R, Xueping E, Christie C, Newell J, Fain S, Altes TA, Castro M: Airway remodeling measured by multidetector CT is increased in severe asthma and correlates with pathology. Chest 2008; 134:1183-1191.

-12 Scarpa MC, Baraldo S, Marian E, Turato G, Calabrese F, Saetta M, Maestrelli P: Ceramide expression and cell homeostasis in chronic obstructive pulmonary disease. Respiration 2013;85:342-349. 